\title{
Extent of the Latitudes and Limits of the Social Media, and Freedom of Expression within the Confines of Law in Nigeria
}

\author{
E.Q. Okolie Esq LLB, (Hons.) BL, LLM, Ph.D FIPMD, \\ Senior Lecturer and Former Head of Department, Faculty of Law, Chukwuemeka Odumegwu Ojukwu \\ University, Igbariam Campus, Anambra State, Nigeria
}

\begin{abstract}
Generally speaking, an egalitarian society flourishes on free speech. A speech is considered free when expressed without any form of restraint or threat whether physical or psychological. Modern trends in communication emanating from globalization has eroded territorial barriers that hitherto existed in disseminating information. In fact, by a click of a mouse, a simple message is received by a limitless audience. This form of advancement in technology in the are of the dissemination of information is facilitated by the Internet, which surpasses the traditional means of communication such as the television, radio, post office, and the print media. More particularly the modern social media that exist in the form of Facebook, Linkedln, Twitter, WhatsApp, Badoo, Instagram, u-tube etcetera, permits users to disseminate information effortlessly at their comfort zones. This paper juxtaposes the intersection between social media, the law and freedom of expression by exploring the extent of their latitudes and limits, within the law. The paper xrays what constitutes freedom of expression in the online world within the ambit of the relevant provision of the Nigerian law. In addition, the paper investigates the extent and limits of the social media in promoting freedom of expression in Nigeria.
\end{abstract}

Keywords: social media, freedom of expression, Nigerian law

DOI: $10.7176 / J L P G / 83-20$

\section{Introduction}

The conduit through which one person or group of persons disseminates information or ideas and received same by targeted audience is referred to as the medium of communication. This connotes the use of alternate means and devices such as televisions, radio, newspapers, magazines etc. The expression media is a plural of medium; as such, mass media is a means by which messages are passed to different categories of people from time to time. ${ }^{1}$ Traditionally, the province of the media was confined to print and electronic media but due to the evolving nature of communication and social formation; social media has evolved to a prominent position in the communication industry. Therefore, the use of dedicated websites and applications to communicate with other users is known as Social Media. ${ }^{2}$ Accordingly, the use of internet-aided facilities for the exchange of services, information, personal believes or interest and ideas, in the form of video, images, documents files and music entails the use of social media. The most noticeable social media in use includes Facebook, Twitter, WhatsApp, Yahoo Messenger, YouTube, Skype, Linkedln etcetera.

Social media has continued to evolve as an indispensable branch of a tree that could be called human interaction, to wit, social formation, which is not complete in almost all parts of the world without a touch of the social media. Almost every part of daily living and social intercourse has a touch or flavor of social media. This is borne out of its functional benefits and aesthetic addition to our regular lives. No matter the side of the divide you belong, you will readily agree with the assertion that social media is a ready tool for all who have access to it and equally a willing tool or help to everyone without discrimination across boundaries. The growth and importance of social media is readily apparent. For instance in the last fourteen years, Facebook has grown from leaps and bounds as a start-up to a global phenomenon with 2.19 billion active monthly users, more than a fifth of the world population. ${ }^{3}$ In fact, due to its unique qualities and easy access it has proven to a tool of unity for different groups both in time of peace, relative peace and turmoil or disturbance. Further, its ease of access could also be used to forward dangerous and illegal activities that threatens peaceful co-existence of man.

The phenomenal growth of social media is largely because it is different from traditional forms of media and social interaction in a number of significant ways. One way is spontaneity -without any delay or ceremony users

\footnotetext{
${ }^{1}$ Merriam Webster Dictionary, available at https://www.merriam-webster:com/dictionary/communication (accessed 12 May 2018).

2 Ibid

${ }^{3}$ Statistics Portal, 'Number of monthly active Facebook users worldwide as of 1st quarter 2018 (in millions)' (2018) https://www.statista.com/statis tics/264810/number-of-monthly-active-facebook-users-worldwide/ (accessed 28 May 2018).
} 
on the spot can post pictures, video recordings of live events, Tweet, or send comments from almost any spot in the world where there is internet access without any limitations. Secondly, social media provides an instant audience, across the planet earth which could run into millions of receivers. Thirdly, it affords an opportunity to preserve the message in a permanent form. Social media messages can be saved, archived or reposted and this process chain is very difficult to erase or delete. This also has its disadvantages, especially when the disseminated messages were not really intended to be circulated or said without much thought and equally contain information that could be termed offensive or sent in bad thought.

In reality, social media has become both an effective and indispensable mode of social intercourse whereby vital information and ideas could be communicated and within a short interval, such information could become viral across boundaries and territory. In essence, enjoyment of basic fundamental rights like freedom of expression and association is buoyed or enhanced with contemporary developments or advancement in technology, which has continued to reflect in the types of tools used for social media. For instance, mass action or mob action can now be organized and executed with ease with latest development in social media; information and news could be disseminated as it is happening and actions and responses could be activated and felt at the same time without any loss in tempo. Further, it is trite that every rights always involve corresponding obligation, thus while freedom of expression enjoys a turbo effect from the platform of social media, it remains important that the wider spectrum provided for us to enjoy this freedom is not without limitations. ${ }^{1}$ Some of these limitations are expressly provided for in the 1999 Constitution of Nigeria. Section 39 (2) of the Constitution of the Federal Republic of Nigeria in the following words:

Nothing in the section shall invalidate any law that is reasonably justifiable in a democratic society-

(a) For the purpose of preventing the disclosure of information received in confidence, maintaining the authority and independence of courts or regulating telephone, wireless television or the exhibition of cinematograph Films; or,

(b) Imposing restrictions upon persons holding office under the government of the federation or of a state, members of the armed forces of the federation or members of the Nigeria police force.

Other limitations could also be found in some legislation in force that pertain to social media and dissemination of information generally. ${ }^{2}$ This is particularly necessary in order to prevent or minimize the risk of abuse of the social media, for example children and young persons who have access to computer need to be given some level of safeguard and practically shielded from cyber predators and abusers some of who have been discovered to prey on the innocence or naivety of children and young people exposed to the use of internet.

While it is not in doubt that social media serves many good purpose, it is also known to have many social disadvantages or less desirable impacts on the society. For instance, fake news and dissemination of inappropriate information and virtual contents have continued to be on the increase with internet facilities now available to a large portion of the people on the planet earth. Further regulation of social media should be a balancing act in order not to kill both the creativity and the high level of entrepreneurship spirit that led to the success of some of these social media tools or platform.

Consequently, this article attempts to explore the evolving nature of social media, its relation to the provisions of the law within the boundaries of freedom of expression and the wider interest of the society. This paper is divided into seven parts with the first part being the introductory section. Part two explores the freedom of expression and social media while part three examines the connection between social media and the law. Part four deals with the restrictions on freedom of expression while part five investigates the limits of social media in Nigeria. Part six makes recommendations with the last part being the concluding part of the paper.

\footnotetext{
${ }^{1}$ International Covenant on Civil and Political Rights, 1966 (ICCPR) is one of the international conventions that supports freedom of expression. In Article 19 (2), it provides as follows: Everyone shall have the right to hold opinions without interference. Everyone shall have the right to freedom of expression; this right shall include freedom to seek, receive and impart information and ideas of all kinds, regardless of frontiers, either orally, in writing or in print, in the form of art, or through any other media of his choice'. But in Article 19(3) it imposes restrictions on the enjoyment of this provision or right. ${ }^{2}$ For example Article 19 of the Universal Declaration of Human Rights (UDHR) and the International Covenant on Civil and Political Rights (ICCPR), provides that: (i)Everyone shall have the right to hold opinions without interference, (ii) Everyone shall have the right to freedom of expression; this right shall include freedom to seek, receive and impart information and ideas of all kinds, regardless of frontiers, orally, either in writing or in print, in the form of art, or through any other media of his choice.
} 


\section{Freedom of Expression and the Social Media}

Historically, freedom of expression gain recognition with the invention of the printing press by Johannes Gutenberg when there was a massive dissemination of information and opinions. This was followed by the advent of the radio and later the television in the twentieth century. ${ }^{1}$ These medium of communication were so potent to facilitate political agendas. For instance, they could be used to topple or install political regimes. ${ }^{2}$ More importantly, freedom of expression is revered because it is essential to human integrity, without which the human identity becomes meaningless.

The ability of humans to express themselves through either words, music dance or paintings is what distinguish them with other primates such as apes. Furthermore, freedom of expression is the fulcrum of other rights such as the right to self-determination and human dignity. The absence of the freedom of expression means the inability to organize or mobilize others in defense of other fundamental rights. It is when freedom of expression have a public form that it becomes meaningful, and this can only be possible in a free and vibrant medium. ${ }^{3}$ This is where the social media has proved to be transformative. The social media re-affirms these core values by offering users the ability to create and edit contents, giving all opportunity to become an author. This was expressed by a UNESCO report as follows:

Technological convergence has expanded the number of and access to media platforms as well as the potential for expression. It has enabled the emergence of citizen journalism and spaces for independent media, while at the same time fundamentally reconfiguring journalistic practices and the business of news. ${ }^{4}$

The development brought about by social media has also brought along with it a chaotic situation which did not only prove to be difficult to understand, but also difficult to regulate, as the domain is very fluid and subject to manipulation that left the government grappling for answers as to who control user- generated contents.

\section{Social Media and the Law}

Law is generally understood not to operate in vacuum, and as such law is a reflection of society where it operates. According to Thomas Hobbes, 'life outside society would be 'solitary, poor, nasty, brutish, and short'. However, he went further to proffer a solution out of such an undesirable situation. The solution he advocated was to put some powerful individual or parliament in charge who becomes the lawgiver and possibly lays down how the law would be executed or administered. ${ }^{6}$ Thus, social media without proper regulation could easily lead to undesirable situation. This is not a novel situation, rather it is just a hybrid of press freedom or freedom of expression.

In essence, the legitimacy of social media is traced to the freedom of expression as provided by International and National legal instruments particularly, the Universal Declaration of Human Rights (UDHR) and the International Covenant on Civil and Political Rights (ICCPR), which states as follows:

i. Everyone shall have the right to hold opinions without interference.

ii. Everyone shall have the right to freedom of expression; this right shall include freedom to seek, receive and impart information and ideas of all kinds, regardless of frontiers, orally, either in writing or in print, in the form of art, or through any other media of his choice. ${ }^{7}$

The Constitution of the Federal Republic of Nigeria (as amended) states that "Every person shall be entitled to freedom of expression; including freedom to hold opinions and to receive and impact ideas and information without interference." $"$ This provision of the constitution implies that every citizen of Nigeria is free to use the social media to express his opinion, though subject to certain limitations which among others include preventing the disclosure of information received in confidence; maintaining the authority and independence of courts or regulating telephone, wireless television or the exhibition of cinematograph Films; or, Imposing restrictions upon

\footnotetext{
${ }^{1}$ Martin, James B. (2002). Mass Media: a bibliography with indexes. Nova. ISBN 978-1-59033-262-7.

${ }^{2}$ Cass R. Sunstein, Republic: Divided Democracy in the Age of Social Media (Princeton: Princeton University Press, 2018).

3 Amartya Sen, Development as Freedom (Oxford: Oxford University Press, 1999).

${ }^{4}$ UNESCO, World Trends in Freedom of Expression and Media Development (2014). http://unesdoc.unesco.org/images/0022/002270/227Q25e.pdf (accessed 20 May 2018).

${ }^{5}$ Thomas Hobbes, Leviathan, Accessed 29-05-2018॥\https://ebooks.adelaide.edii.au/ri/hobbes/thomas/h681/ index.html.

${ }^{6}$ Ibid

${ }^{7}$ Article 19 of the UDHR and ICCPR.

${ }^{8}$ Section 39(1) of the 1999 Constitution of the Federal Republic of Nigeria, as amended 2010
} 
persons holding office under the government of the federation or of a state, members of the armed forces of the federation or members of the Nigeria police force. ${ }^{1}$

However, the uniqueness of the social media poses certain challenges to the law. In other words, social media gives users the ability to not only receive information, but also to moderate information. Most users of the social media are not licensed journalist who are required to adhere to conventional ethics of journalism, but are merely over excited people who wish to disseminate information by virtue of a click of the mouse or a tap on a post. ${ }^{2}$ Thus, the liberty to express oneself has breached the requirements of; fairness, reasonability and proportionality. The foregoing attributes of the social media renders it distinct from the traditional mass media, where information must be authenticated before dissemination, and where it is disseminated; it cannot be easily moderated. As such an existence of restricted freedom of expression. Arguably, every individual has the right to publish freely in whatever form including the social media as envisaged by the fundamental right to freedom of expression. This underscore the fact that with the present level of technological development and globalization expression or communication of ideas and information is fast asserting itself as a genre of fundamental human rights that needs little or no formal assistance to find manifestation. In the United States for example, its constitution gives priority to freedom of speech and the press than all other rights, including right to life and personal liberty. ${ }^{3}$ In essence, freedom of speech and the press are more jealously guarded against governmental encroachment and cherished above other rights. ${ }^{4}$ This position is supported by the assertion of Nwabueze that speech is an irrepressible attribute of man. ${ }^{5}$ According to him:

So long as he lives he cannot be prevented from speaking if he wants to do so. You can punish him for what he says, but that is after he has said it. Gagging apart, it is physically impossible to prevent a living person from speaking what he pleases. His audience may be restricted by government regulation banning assemblages of persons in public places, but he remains free to speak his mind privately if he has the courage to damn the consequences. ${ }^{6}$

Furthermore, it is established and generally accepted that man is a social animal thus for man's freedom of expression is an indispensable tool or medium in social formation and decision-making process in any society. This view was lend credence to by the president of the International Court on Human Rights as follows: Freedom of expression is a cornerstone upon which the very existence of a democratic society rests. It is indispensable for the formation of public opinion. It is also a condition sine qua non for the development of political parties, trade unions and scientific and cultural societies and, in general, those who wish to influence the public. It represents in short, the means that enables the community, when expressing its opinion, to be sufficiently informed. It is the condition of social life that allows members of the society to reach the highest level of personal development and the optimum achievement of democratic values. ${ }^{7}$

Generally, use of social networks involve the processing of personal data and thus engage privacy and data protection laws which cannot be overlooked in contemporary times. With the advent of new technologies, this will pose new challenges for the traditional concepts of privacy. ${ }^{8}$ Consequently, it could be seen from the foregoing that social media is not just for a social interaction rather its practical significance touches on the essence of practical living and its protection via freedom of expression and the press gives value to the enjoyment of other categories of rights in the society. It gives ensures sustainability of the society because what is the value of a right to life that can neither express its thoughts or ideas through any reasonable means or social medium.

\section{4. $\quad$ Restrictions on Freedom of Expression}

Restricting freedom of expression on the social media is known as censorship. Censorship is resorted to where allowing the information will result in a chaotic situation that will likely affect the integrity of the State, community or individual. The major challenge to social media censorship is erosion territorial borders and

\footnotetext{
${ }^{1}$ Section 39 (2) of the Constitution of the Federal Republic of Nigeria, 1999.

${ }^{2}$ Govindarajan, G., \& Ravindar, N. FREEDOM OF EXPRESSION ON SOCIAL MEDIA: MYTH OR REALITY.

${ }^{3}$ Freedora of the press is established in the First Amendment of the United States Constitution, which states that "Congress shall make no law... abridging the freedom of speech, or of the press." See B.O. Nwabueze, The Presidential Constitution of Nigeria (London: C. Hurst \& Company in association with Nwamife Publishers, 1982), 457.

${ }^{4}$ Ibid

${ }^{5}$ K.M. Mowoe, Constitutional Law in Nigeria (Lagos: Malthouse Press Ltd., 2008), 441.

${ }^{6}$ B.O. Nwabueze, The Presidential Constitution of Nigeria (London: C.Hurst \& Company in association with Nwamife Publishers, 1982), 457.

${ }^{7}$ Advisory Opinion OC 5/85 8 EHRR, 168 (1985).

8 Dorothy J. Glancy, 'The invention of the right to privacy' (1979)21:1 Arizona Law Review 1
} 
expansive nature of social media. Where social media is used in expressing an opinion or idea, the entire world receives such content irrespective of whether it legal in the country of origin or not. This could be attributed to several factors such as, absence of self-verification of facts before posting contents online, leading to the proliferation of rumors, hate speech, sedition, etc. As a result, the government will not be wrong in restricting contents uploaded on social media.

In Nigeria, restrictions on the freedom of expression is generally placed by the Constitution of Federal Republic of Nigeria, 1999 (as amended), Even though there was an attempt in enacting specific legislation for controlling the social media known as the "Frivolous Petition Prohibition Bill 2015.' The process was jettisoned because of the criticism that followed. Freedom of expression on the social media usually flows from the freedom of the press. Hence, censorship of the social media is also intertwined with that of the press in any country. In contrast to other countries such as; North Korea, Saudi Arabia, Iran, China and Cuba, users of social media in Nigeria enjoys a very high degree of latitude in expressing views, ideas and opinions on broad perspectives. ${ }^{1}$ For example, all websites in North Korea are subject to government control. Similarly, in Cuba, the internet is only provided in government controlled "access points", and user activity online is monitored by virtue of keyword filtering and browsing history checking and content upload on the social media is restricted to only pro-

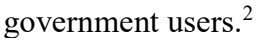

\section{Limits of the Social Media in Nigeria}

While freedom of expression is guaranteed under the UDHR, ICCPR and the Constitution of the Federal Republic of Nigeria, 1999, it does not mean that there is no legal control whatsoever on the fundamental right of freedom of expression. In era of'fake news', 'online terrorism', 'online hatred' and 'online bullying', 'hate speeches' control is necessary in order is to ensure that free speech does not transgress over the right to privacy and dignity of others, especially in the form of mischievous and defamatory publications. Accordingly, "the same right that people have offline must also be protected online." 3 To this end, users of social media owe a duty in observing decency on what they disseminate over the internet. Freedom of expression on the social media is re-echoed in Article 19 of the UDHR, which provides:

Everyone has the right to freedom of opinion and expression; this right includes freedom to hold opinions without interference and to seek, receive and impart information and ideas through any media and regardless of frontiers.

The implication of the provision of the law above envisages the law is flexible and capable of accommodating future technological innovations in the communication sector. As stressed by Andrew Puddephatt, Executive Director Global Partners Digital as follows:

The internet a powerful technology that has major implications for freedom of expression. Its interactivity means people can become creators, co-creators, curators or editors, and not just consumers of content, and communication is peer-to-peer rather than hierarchical. Nor was the internet built to a central design - anyone can add to the it. It is a dynamic environment, shaped by permission less innovation, adaptive and constantly changing, like an organic evolving ecosystem. ${ }^{4}$

Having discussed the concept of freedom of expression in the preceding section, it becomes pertinent to pose the question, 'is there freedom of expression on the social media in Nigeria?' According to the Nigerian Communication Commission, there about 91 million users of social media. ${ }^{5}$ This places Nigeria as the eighth country with most internet users globally. Out of this figure, 7.2 million Nigerians access either Facebook or WhatsApp daily where $97 \%$ does this through mobile devices. ${ }^{6}$ The effects of the social media in Nigeria was visible in the Bring Back Our Girls (\#BBOG) campaigns and the 2015 general elections ${ }^{7}$. The CEO of Facebook Mark Zuckerberg's also attests this trend on his visit to Nigeria when he stated that; "with over 18 million Facebook users in Nigeria, he and his team were working to provide more access to the internet through the 'Free Basic' Initiative."8 However, a true test of the freedom of expression on the social media in Nigeria will

\footnotetext{
${ }^{1}$ Committee to Protect Journalists, '10 Most Censored Countries' https://cpj.org/2015/04/10-most-censoredcoimtries.php (accessed 15 May 2018).

${ }^{2}$ Emilo San Pedro, 'Cuba Internet Access Still Severely Restricted' (21 March 2016) BBC News, Miami littp://www.bbc.com/news/world-1 atin-america-3 5865283 (accessed on 17 May 2018).

${ }^{3}$ Article United Nations Human Rights Commission, https://www.artjclel9.org/resources/article-19-at-the-unhrc-thej: sainerights-that-peopie-have-offline-must-aisQ-be-protected-online/ (Accessed 25 May 2018).

${ }^{4}$ Puddephatt, A. (2011). Freedom of Expression Rights in the Digital Age. Open Society Foundation: Washington.

${ }^{5}$ Adomi, E. E. (2005). Internet development and connectivity in Nigeria. Program, 39(3), 257-268.

${ }^{6}$ Ibid

${ }^{7}$ See http://www.bringbackourgirjs.ng/. (Accessed 30 May 2018).

${ }^{8}$ Why I came to Nigeria-Facebook founder, Mark Zuckerberg. Available at
} 
only be appreciated when there is a specific law regulating social media in Nigeria. That will present an opportunity for case law to evolve.

\section{Conclusion}

Social media presents a rich avenue for the development of law in many areas but critical questions regarding its use, limitations and regulations will soon inevitably become regular issues in our courts for resolution; as interesting and trail blazing it may appear, social media is not working a revolution in the law, but rather is part of the law's slow, steady evolution. Further, it offers a rich source of briefs and ideas for both legal practitioners and jurists.' To this extent we expect a continuous development of "social media law" as a mix of constitutional law, employment law, criminal law, administrative law, intellectual property law, tort law, and contract and commercial law.

Consequently, this article is not intended to serve as a final word on the subject, instead the aim is to contribute to a well-inform debate on a relevant global issue that is still not well explored. The major distinction between social media and the traditional mass media is the ability to control contents with ease.

\section{7. $\quad$ Recommendations}

Freedom of expression on the social media is assured where the content and the means by which the content is safeguarded. In the offline world, it is settled that the right to freedom of expression is not absolute, that derogations is permitted in exceptional circumstances. These derogations to freedom of expression are if provided for by law and are necessary (a) to protect the rights or reputations of others and (b) for the protection of national security, public order, public health or morals. Any restriction should also be proportionate, legitimate and in accordance with democratic values. Filtering and blocking softwares can be circumvented as mobile phone can stream contents directly to the web.

By way of recommendation, law and policy should protect freedom of expression, and if at all necessary, restrictions on freedom of expression on the social media should be subject to judicial review and be compliant with human rights norms and best practices. The National Assembly must as a matter of urgency, amend all laws dealing with regular or traditional media to accommodate the social media. This is underscored by the fact that apart from the issue of freedom of expression, social media can equally raise a host of questions regarding intellectual property, including copyright, privacy, cyber bullying and employment related issues.

https://www. daiiytrust.com. ng/news/news/why-i-came-to-nigeria-facebook-founder-mark-zuckerberg/ 160750.html. (Accessed 26 May 2018). 